\title{
IN VITRO ANTI-ARTHRITIC ACTIVITY OF CISSUS QUADRANGULARIS STEM EXTRACT
}

\author{
VAIJAYANTHIMALA P*, SAKTHIPRIYA M, SANGAMESWARAN B
}

Department of Pharmaceutical Chemistry, SSM College of Pharmacy, Erode - 638 312, Tamil Nadu, India. Email: vaijphd2014@gmail.com Received: 17 May 2018, Revised and Accepted: 25 September 2018

\section{ABSTRACT}

Objective: The present investigation deals with the study of in vitro anti-arthritic activity by inhibition of protein denaturation method by bovine serum albumin method and egg albumin method. Cissus quadrangularis Linn plant is a perennial tendril climber with quadrangular stem. It is used in the treatment of gout, syphilis, stomach ache, regularized the menstrual cycle, antimicrobial activity, and piles in Ayurvedic medicine, and traditionally used for the bone fracture.

Method: The air-dried powder of C. quadrangularis Linn (stem parts) was extracted using a Soxhlet apparatus with methanol C. quadrangularis (MECQ) and aqueous $C$. quadrangularis water (AECQ) as solvent. The extracts were concentrated under reduced pressure. The activities were carried out using the following concentration $(100,200,300,400$, and $500 \mu \mathrm{g} / \mathrm{ml})$ and compared with diclofenac as standard drug. It has significant in vitro anti-arthritic in both the methods.

Result: The extract of C. quadrangularis possessed significant anti-arthritic property in MECQ than compared to AECQ.

Conclusion: Activity may be due to the presence of the chemical profile such as phenolic acid, flavonoid (leuteotin), and $\beta$-sitosterol. The results of the study have suggested in the use of $C$. quadrangularis Linn as a potent anti-arthritic in several applications.

Keywords: Cissus quadrangularis Linn, Anti-arthritic, Bovine serum albumin, Methanol, Diclofenac.

(C) 2019 The Authors. Published by Innovare Academic Sciences Pvt Ltd. This is an open access article under the CC BY license (http://creativecommons. org/licenses/by/4. 0/) DOI: http://dx.doi.org/10.22159/ajpcr.2019.v12i1.27353

\section{INTRODUCTION}

In the very last few decades, there is a tremendous growth in the region of herbal medicine. It is coming popularized in both developing and developed countries due to its natural origin because of its lesser side effects. Herbal remedies provide a lot of drugs for the treatment of internal diseases which are considered to be stubborn and incurable by other system of medicines [1].

Arthritis is an autoimmune disorder characterized by pain, swelling, and inflexibility [2]. Rheumatoid joint inflammation influences more or less $1 \%$ of the populace around the world. Its etiology is still obscure [3]. However, advances in understanding the pathogenesis of the disease have raised the development of new therapeutics, with improved outcomes. Rheumatoid arthritis may quickly progress into a multisystem inflammation with irreversible joint destruction and increase the risk of humanity [4].

Rheumatoid arthritis was defined as "The condition in which Primary Aesthenic Gout. Alfred Garrod established the difference between Rheumatoid arthritis and Gout". Inflammatory diseases which include different types of rheumatoid disease are a major cause of morbidity of the working force all over the world. This also knew as the king of human miseries. Inflammation is a normal protective response to tissue injury caused by physical trauma, noxious chemical, or microbial agents [5,6].

Cissus quadrangularis $\mathrm{L}$. is a plant belonging to the family Vitaceae commonly known as Asthisamhari found in tropical and subtropical xeric wood. It can be found throughout the hotter parts of India alongside hedges and neighboring countries such as Pakistan, Bangladesh, Sri Lanka, and Malaysia [7,8].

\section{MATERIALS AND METHODS}

Materials

Drugs and chemicals

All reagents procured were analytical grade.

\section{Plant collection}

Fresh stem of C. quadrangularis Linn was collected from field of Thalavadi near Erode and authenticated by Dr. M.Palanisamy, Scientist D and Head office in charge, Southern Regional Centre, TNAU campus, Coimbatore. (BSI/SRC/5/23/2017/Tech-2844). A voucher specimen (No: SSMCOP/106/25) has been deposited in the Department of Pharmacognosy, SSM College of Pharmacy, Jambai village, Tamil Nadu, India.

The stem of $C$. quadrangularis Linn was dried and then crushed into fine powder using laboratory homogenizer, then stored for further use.

\section{Preparation of plant extracts}

The crude drugs were extracted with methanol $C$. quadrangularis MECQ and Aqueous C. quadrangularis waterAECQ as a solvent using the Soxhlet apparatus for continuous hot extraction. The extract was filtered and evaporated to separate solvent and residue. The semisolid residue thus obtained was stored in desiccator until further use.

\section{In vitro anti-arthritic activity}

Inhibition of protein denaturation (bovine serum albumin)

Denaturation of tissue protein is one of the well-documented causes of inflammatory and arthritic diseases. Production of the autoantigen in certain arthritic diseases may be due to denaturation of protein in vitro. 
Table 1: Anti-arthritic activity of Cissus quadrangularis by bovine and egg serum albumin method

\begin{tabular}{lll}
\hline Effect of herbal extracts in different concentration & (\%) Inhibition by bovine serum method & (\%) Inhibition by egg albumin method \\
\hline $\begin{array}{l}\text { Control } \\
\text { Diclofenac }\end{array}$ & & \\
$\quad 100 \mu \mathrm{g} / \mathrm{ml}$ & 89.41 & 90.81 \\
Aqueous extract of $C$. quadrangularis & & 8.27 \\
$100 \mu \mathrm{g} / \mathrm{ml}$ & 16.47 & 14.11 \\
$200 \mu \mathrm{g} / \mathrm{ml}$ & 37.64 & 20.52 \\
$300 \mu \mathrm{g} / \mathrm{ml}$ & 43.52 & 36.74 \\
$400 \mu \mathrm{g} / \mathrm{ml}$ & 60.00 & 62.35 \\
$500 \mu \mathrm{g} / \mathrm{ml}$ & 74.11 & \\
$\mathrm{Methanol} \mathrm{extract} \mathrm{of}$ C. quadrangularis & & \\
$100 \mu \mathrm{g} / \mathrm{ml}$ & 36.76 & 21.17 \\
$200 \mu \mathrm{g} / \mathrm{ml}$ & 56.47 & 34.11 \\
$300 \mu \mathrm{g} / \mathrm{ml}$ & 69.41 & 40.29 \\
$400 \mu \mathrm{g} / \mathrm{ml}$ & 67.05 & 82.35 \\
$500 \mu \mathrm{g} / \mathrm{ml}$ & 82.35 & \\
\hline
\end{tabular}

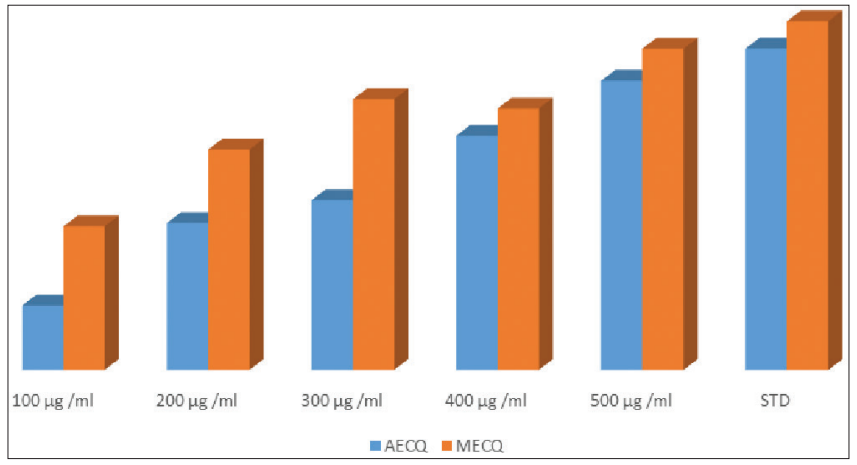

Fig. 1: Anti-arthritic activity of Cissus quadrangularis by bovine serum method

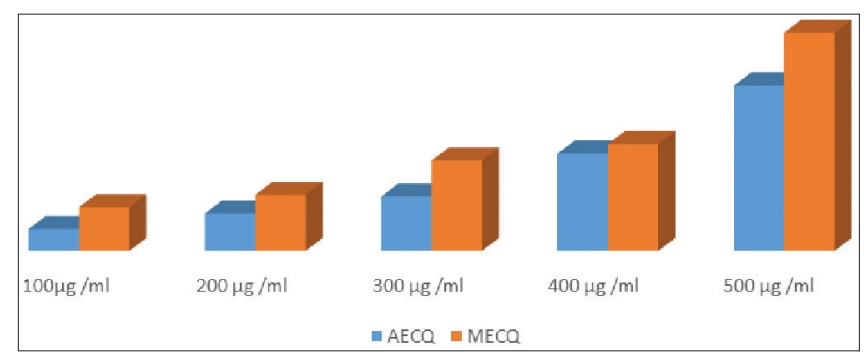

Fig. 2: Anti-arthritic activity of Cissus quadrangularis by egg albumin method

Agents that can prevent protein denaturation, therefore, could be worthwhile for anti-arthritis drug development [9]. Some literatures stated that protein denaturation and macroglobulin formation cause the proteins to become antigenic, thus initiating the immune response and producing biochemical changes in connective tissue, which ultimately leads to rheumatoid arthritis $[10,11]$.

\section{Methods}

The following three solutions were used.

\section{Test solution}

$0.5 \mathrm{ml}$ of test solution consists of $0.45 \mathrm{ml}$ of BSA $(5 \% \mathrm{w} / \mathrm{v})$ and $0.05 \mathrm{ml}$ of extracts in various concentrations $(100,200,300,400$, and $500 \mu \mathrm{g} / \mathrm{ml})$.

\section{Test control solution}

$0.5 \mathrm{ml}$ of test control solution consists of $0.45 \mathrm{ml}$ of BSA ( $5 \% \mathrm{w} / \mathrm{v}$ ) and $0.05 \mathrm{ml}$ of distilled water.

\section{Standard solution}

$0.5 \mathrm{ml}$ of standard solution consists of $0.45 \mathrm{ml}$ of BSA (5\% w/v) and $0.05 \mathrm{ml}$ of diclofenac sodium solution $(100 \mu \mathrm{g} / \mathrm{ml})$.

The $\mathrm{pH}$ of the above solutions was adjusted to 6.3 using a small amount of $1 \mathrm{~N} \mathrm{HCl}$. The samples were incubated at $37^{\circ} \mathrm{C}$ for $20 \mathrm{~min}$ and heated at $57^{\circ} \mathrm{C}$ for $3 \mathrm{~min}$ which were cooled, and $2.5 \mathrm{ml}$ of phosphate buffer (pH 6.3) was added to it. Control represents $100 \%$ proteins. After cooling, their absorbance was measured at $660 \mathrm{~nm}$ using pure blank. Diclofenac sodium (standard drug) was used as reference drug and treated as such for determination of absorbance. The percentage inhibition of protein denaturation was calculated as follows:

Percentage inhibition $=\frac{\text { OD control }- \text { OD sample }}{\text { OD control }}$

\section{Inhibition of albumin denaturation (egg albumin) $[12,13]$}

Methodology

The following three solutions were used.

\section{Test solution}

$5 \mathrm{ml}$ of test solution consists of $0.2 \mathrm{ml}$ of egg albumin and $2.8 \mathrm{ml}$ of phosphate buffer saline and $2 \mathrm{ml}$ of in various concentrations of extracts $(100,200,300,400$, and $500 \mu \mathrm{g} / \mathrm{ml})$.

\section{Test control solution}

$5 \mathrm{ml}$ of test control solution consists of $0.2 \mathrm{ml}$ of egg albumin and $2.8 \mathrm{ml}$ of phosphate buffered saline and $2 \mathrm{ml}$ of distilled water.

\section{Standard solution}

$5 \mathrm{ml}$ of standard solution consists of $0.2 \mathrm{ml}$ of egg albumin and $2.8 \mathrm{ml}$ of phosphate buffer saline and diclofenac $100 \mu \mathrm{g} / \mathrm{ml}$.

The $\mathrm{pH}$ of the above solutions was adjusted to 6.4 using a small amount of $1 \mathrm{~N} \mathrm{HCl}$. The samples were incubated at $37^{\circ} \mathrm{C}$ for $20 \mathrm{~min}$ and heated at $70^{\circ} \mathrm{C}$ for $5 \mathrm{~min}$ denaturations, and the results were compared with standard diclofenac sodium.

After cooling, their absorbance was measured at $660 \mathrm{~nm}$ using pure blank. Diclofenac sodium (standard drug) was used as reference drug and treated as such for the determination of absorbance. The percentage inhibition of protein denaturation was calculated as follows:

Percentage inhibition $=\frac{\text { OD control }- \text { OD sample }}{\text { OD control }}$ 


\section{RESULTS AND DISCUSSIONS}

\section{In vitro anti-arthritic activity}

Hence, the results of our study reveal that extracts of $\mathrm{C}$. quadrangularis were capable of controlling the production of autoantigens and inhibit denaturation of protein especially denaturation of albumin. [14]. The present studies indicate that extracts of $C$. quadrangularis exhibit strong anti-arthritic property which could be a potential source of antiarthritic property.

The inhibition of protein denaturation, albumin denaturation, and membrane stabilization was studied to establish the mechanism of anti-arthritic activity of $C$. quadrangularis. Therefore, our in vitro studies on the extract of $C$. quadrangularis demonstrate the significant anti-arthritic activity. Hence, this mangrove plant can be used as a potent natural anti-arthritic agent. The results show that the extracts of $C$. quadrangularis exhibiting anti-arthritic activities might be due to the presence of active principles such as polyphenolic content, triterpenoids, alkaloids, and flavonoids. From the results of the study, it can be concluded that the extract of $C$. quadrangularis possessed significant antiarthritic property in MECQ than compared to AECQ. The present study revealed the potential of plant extract in the management of inflammation and arthritis confirming the folk core use of medicinal plants. However, one should try to further figure out extract more as having much better activity in the quest of active candidate or chemical molecule that is mainly responsible for this activity through detailed experimentation (Table 1 and Fig. 1 and 2).

\section{Statistical analysis}

All the results were expressed as mean \pm standard deviation, and all the grouped data were statistically evaluated with GraphPad prism. Hypothesis testing methods included one-way analysis of variance followed by least significant difference test.

\section{ACKNOWLEDGMENT}

This research was supported by Vyrathi Charitable Trust. We are highly thankful for our chairperson and correspondent for providing for encouragement and availing of the laboratory facilities during the course of the investigation. We also thank Sathya M, Shajudeen R, and Subash Chandrabose for their contribution.

\section{AUTHORS' CONTRIBUTIONS}

All the authors contributed equally to conductance of the study, writing, and editing the article.

\section{CONFLICTS OF INTEREST}

The manuscript represents valid work,neither this manuscript nor one with substantially similar content under my authership has been published or being consider to publication elsewhere.I confirm that work is an accurate representation of the trial results.

\section{REFERENCES}

1. Vaijayanthimala P, Sureshkumar S, Sangameswaran B. Gastroprotective activity of Cucumis sativus. World J Pharm Pharm Sci 2015;4:457-64.

2. Srikanth N, Elumalai A, Eswaraiah MC, Veldi N. An updated review on anti-arthritic medicinal plant. Int J Pharm Sci Rev Res 2012;2:11-5.

3. Montecucco F, Mach F. Common inflammatory mediators orchestrate pathophysiological processes in rheumatoid arthritis and atherosclerosis. Rheumatology 2009;48:11-2.

4. Wang M, Li K, Nie Y, Wei Y, Li X. A network study of Chinese medicine xuesaitong injection to elucidate a complex mode of action with multicompound, multitarget, and multipathway. Evid Based Complement Alternat Med 2012;12:1-10.

5. Pavithra TK, Smitha KP, Kulashekar KS, Kumar BS. Evaluation of in vitro anti-arthritic activity of Vitex negundo against the denaturation of protein. Int J Curr Microbiol Appl Sci 2015;4:87-90.

6. Jagtap VA, Agasimundim YS, Jayachandran E, Sathes BS. In vitro anti-inflammatory activity of 2- amino-3-(substituted benzylidine carbohydrazide)-4,5,6,7- tetrahydrobenzo-thiophenes. J Pharm Res 2011;4:378-9.

7. Sumanya H, Lavanya R, Reddy C. Evaluation of in vitro anti-oxidant and anti-arthritic activity of methanolic extract of marine green algae Caulerpa racemosa. Int J Pharm Pharm Sci 2015;7:340-3.

8. Ghouse MS. A pharmacognostical review on Cissus quadrangularis Linn. Int J Res Pharm Biosci 2015;2:28-35.

9. Kumari CS, Yasmin1 N, Raffiq M, Hussain N, Babuselvam M. In vitro anti-inflammatory and anti-arthritic property of Rhizopora mucronata leaves. Int J Pharm Sci Res 2016;6:482-5

10. Lavanya R, Maheshwari SU, Harish G, Raj JB, Kamali S, Hemamalani D. Investigation of in vitro anti-inflammatory, anti-platelet and antiarthritic activities in the leaves of Anisomeles malabarica Linn. Res J Pharm Biol Chem Sci 2010;1:746-52.

11. Srividya S, Sridevi G. Anti-arthritic and anti-inflammatory activity of ethanolic leaf extract of Ormocarpum sennoides. Int J Pharm Pharm Sci 2016;8:117-21

12. Mizushima Y, Kobayashi M. Interaction of anti-inflammatory drugs with serum proteins, especially with some biologically active proteins. J Pharm Pharmacol 1968;20:169-73.

13. Chandra S, Chatterjee P, Dey P, Bhattacharya S. Evaluation of antiinflammatory effect of ashwagandha: A preliminary study in vitro. Pharmacogn J 2012;4:47-9.

14. Sangeetha M, Kousalya K, Lavanya R, Sowmya C, Chamundeeswari D, Maheswara UC. In vitro antiinflammatory and anti-arthritic activity of leaves of Clerodendron inerme. Res J Pharm Biol Chem Sci 2011;2:822-7. 